\title{
Novel molecular targets associated with testicular dysgenesis induced by gestational exposure to diethylhexyl phthalate in the rat: a role for estradiol
}

\author{
Gary R Klinefelter, John W Laskey, Witold M Winnik, Juan D Suarez, Naomi L Roberts, \\ Lillian F Strader, Brandy W Riffle ${ }^{2}$ and D N Rao Veeramachaneni ${ }^{3}$
}

United States Environmental Protection Agency, Office of Research and Development, Toxicology Assessment Division, National Health and Environmental Effects Research Laboratory, Reproductive Toxicology Branch, MD\#72, Reproductive Toxicology Facility, Durham, North Carolina 27713, USA, ${ }^{1}$ National Health and Environmental Effects Research Laboratory, Proteomic Research Core, Durham, North Carolina 27711, USA, ${ }^{2}$ Toxicology Assessment Division, National Health and Environmental Effects Research Laboratory, Endocrine Toxicology Branch, MD\#72, Reproductive Toxicology Facility, Durham, North Carolina 27713, USA and ${ }^{3}$ Animal Reproduction and Biotechnology Laboratory, Colorado State University, Fort Collins, Colorado 80523-1683, USA

Correspondence should be addressed to G R Klinefelter; Email: klinefelter.gary@epa.gov

\begin{abstract}
Significant research has been focused on phthalate-induced alterations in male reproductive development. Studies on rodents have prompted the notion that a syndrome exists in the human male which includes phenotypic alterations such as hypospadias, cryptorchidism, poor semen quality, and even testicular cancer. Each phenotype in this 'testicular dysgenesis syndrome' is predicated on reduction in testosterone production by the fetal Leydig cell. We sought to examine the relationship between dysgenesis and steroidogenic capacity in the fetal rat testis more stringently by incorporating lower exposures than those typically used, conducting a comprehensive, non-targeted quantitative evaluation of the fetal testis proteome, and relating alterations in individual proteins to the capacity of the fetal Leydig cell to produce testosterone, and histopathology of the fetal testis. Pregnant dams were dosed orally from gestation day (GD) 13-19 with 0, 10, or $100 \mathrm{mg}$ diethylhexyl phthalate (DEHP)/kg body weight per day. Each endpoint was represented by $16 \mathrm{I}$. Clustering of Leydig cells occurred before any significant decrease in the capacity of the GD19 Leydig cell to produce testosterone. At $100 \mathrm{mg}$ DEHP/kg, testosterone production was reduced significantly, Leydig cell clusters became quite large, and additional dysgenetic changes were observed in the fetal testis. Of 23 proteins whose expression was altered significantly at both DEHP exposure levels, seven were found to be correlated with and predictive of the quantified endpoints. None of these proteins have been previously implicated with DEHP exposure. Notably, pathway analysis revealed that these seven proteins fit a pathway network in which each is regulated directly or indirectly by estradiol.
\end{abstract}

Reproduction (2012) 144 747-761

\section{Introduction}

A potential decline in human male reproductive health (i.e. semen quality, hypospadias, cryptorchidism, and testicular cancer) and a link to exposure to endocrine active chemicals in the environment have been controversial for almost two decades (Carlsen et al. 1992, Fisch 2008, Sharpe \& Skakkebaek 2008, Akre \& Richiardi 2009). Numerous epidemiology studies have focused on exposure to phthalates and their ability to compromise semen quality in men (Pant et al. 2008, Swan 2008). There has also been an effort to relate phthalate exposure to developmental landmarks such as anogenital distance, penile size, and testis descent (Meeker et al. 2009). Definitive correlations between gestational exposures and adverse outcomes at adulthood are lacking.

Studies on laboratory animals have shown that exposure to 500-750 mg dibutyl phthalate (DBP)/kg during the critical period of male reproductive development, i.e. gestation day (GD) 12-19, results in remarkable phenotypic alterations in normal development (Mylchreest et al. 1998, 2000). At birth, males presented with reduced anogenital distance. At adulthood, the phenotypes included cryptorchidism, epididymal agenesis, testicular atrophy with germ cell loss, hypospadias, and absent or smaller seminal vesicles and prostate. These phenotypes can be linked to androgen deprivation during the critical period of sexual differentiation. Rats exposed to $750 \mathrm{mg}$ diethylhexyl phthalate (DEHP)/kg 
between GD12 and 19 resulted in testes containing large aggregates or clusters of Leydig cells in the interstitial spaces, multinucleated germ cells in the seminiferous cords, and significant reductions in testosterone levels in the GD19 testis (Parks et al. 2000).

By virtue of these phthalate-induced alterations in the rat, a link between comparable human male reproductive disorders and androgen deprivation during fetal development has been suggested. Thus, manifestation of reproductive anomalies such as hypospadias, Sertoli cell-only seminiferous tubules, low sperm counts, and testicular cancer has been termed as the testicular dysgenesis syndrome (TDS; Sharpe \& Skakkebaek 2008). However, it should be noted that Sertoli cellonly tubules and reduced sperm numbers can result from fetal or adult exposures to chemicals that do not decrease testosterone production by the Leydig cells.

In contrast to rat studies, when fetal male mice were exposed to $500 \mathrm{mg}$ DBP/kg during gestation, some signs of testicular dysgenesis were observed such as increased seminiferous cord diameter and increased numbers of multinucleated germ cells, but there was no decrease in testicular testosterone (Gaido et al. 2007). Doses up to $1500 \mathrm{mg} / \mathrm{kg}$ failed to decrease fetal testicular testosterone. Later, it was suggested that phthalate-induced alterations during germ cell development were independent of steroidogenic status (Lehraiki et al. 2009). These authors used fetal mouse testis organ cultures to establish that mono-(2-ethylhexyl) phthalate (MEHP) induced germ cell apoptosis. The number of multinucleated germ cells increased and the number of gonocytes decreased in the absence of steroidogenic change. Interestingly, in both of these studies (one in vivo, one in vitro), there was no evidence of phthalate-induced Leydig cell aggregation.

The responses of fetal rat and human testis explants exposed to monobutyl phthalate (MBP) in vitro also differed, with modest reductions in testosterone production and modest increases in Leydig cell aggregation observed in rat explants but not in human explants (Hallmark et al. 2007). Fetal human testis explants exposed to MEHP also failed to exhibit any changes in testosterone production although germ cell loss was observed; Leydig cell aggregation was not evaluated (Lambrot et al. 2009). Recently, when fetal human testis or fetal rat testis explants were xenografted into castrate male nude mice and exposed to DBP, serum testosterone was compromised in mice with rat testis grafts but not in mice with human testis grafts (Mitchell et al. 2012). Collectively the data support the notion that fetal mouse and human testes respond differently to phthalates than the fetal rat testis. Although Leydig cell aggregation seems to be consistent with decreased testosterone in fetal rat testis, it is not clear if dysgenesis of the fetal Leydig cell population precedes or follows steroidogenic dysfunction.
In an attempt to explain phthalate-induced steroidogenic compromise observed in the rat, numerous studies have sought transcriptional guidance by quantifying the expression of molecules known to be regulated in steroidogenesis such as StAR protein (StAR), P450 sidechain cleavage enzyme (P450scc), and P450 C-17 hydroxylase/lyase (P450c17). In general, the expression of P450scc and P450c17 is not significantly altered until relatively high doses of phthalates are administered (500 mg DBP/kg; Shultz et al. (2001) and Lehmann et al. (2004)) whereas StAR's gene expression decreased at $50 \mathrm{mg}$ DBP/kg (Lehmann et al. 2004) and $100 \mathrm{mg}$ DEHP/kg (Borch et al. 2006). The importance of the posttranscriptional products (i.e. the proteins) in the paths to phenotypes resulting from gestational exposure to phthalate is obvious. Yet only a few studies have sought to identify alterations in protein expression in the testis in a comprehensive, non-targeted fashion (Plummer et al. 2007, Zhang et al. 2007), and these studies used relatively high doses.

Except for one study in which pregnant rats were exposed to doses 10, 100, and $750 \mathrm{mg}$ DEHP/kg (Lin et al. 2008), there have been few in vivo studies of phthalates where low doses (i.e. $<100 \mathrm{mg} / \mathrm{kg}$ ) were used. Lin et al. (2008) observed Leydig cell clusters at 10 and $100 \mathrm{mg}$ and the Leydig cells were decreased in both size and number. As pre-term infants can be exposed to 10-20 mg/day (Agency for Toxic Substances and Disease Registry 2006), we wanted to more carefully evaluate the dose response for the $10-100 \mathrm{mg} / \mathrm{kg}$ range. Thus, we sought to evaluate the complete testis proteome in the fetal rat testis following exposure to these doses during GD13-GD19 compared with the control testis. The objectives of this study were to i) determine whether dysgenesis in the fetal testis precedes a significant change in the ability of the fetal Leydig cell to produce testosterone, ii) identify proteins that are upregulated or downregulated at both 10 and $100 \mathrm{mg} / \mathrm{kg}$ exposures, iii) correlate proteins that are upregulated or downregulated by DEHP to alterations in both the steroidogenic capacity and aggregation of the GD19 Leydig cells, and iv) select proteins that are predictive of alterations in both steroidogenic capacity and aggregation of the GD19 Leydig cells. Once proteins that are correlated with or predictive of specific endpoints were determined, they were submitted for pathway analysis. The identification of predictive biomarkers and adverse outcome pathways provides a basis for the development of more sensitive and quantitative assays with the potential to predict an adverse outcome in humans.

\section{Results}

\section{Alterations in testis histology}

Dysgenesis was obvious in the GD19 testis following exposure to both 10 and $100 \mathrm{mg} \mathrm{DEHP} / \mathrm{kg}$, hereafter 
referred to simply as 10 and $100 \mathrm{mg}$. Even with $10 \mathrm{mg}$ exposure, Leydig cell clustering in the interstitium of the testis was evident (Fig. 1B). Following $100 \mathrm{mg}$, the clustering of the cells was more remarkable as large clusters containing many Leydig cells were frequently observed (Fig. 1C). Gonocyte-like cells could be found in the interstitium rather than solely localized within seminiferous cords (Fig. 1C and Supplementary Figure 1, see section on supplementary data given at the end of this article) and erythrophagosomes resulting from extravasated erythrocytes were also evident in the interstitium (Fig. 1C and Supplementary Figure 2, see section on supplementary data given at the end of this article). Finally, it was not uncommon to find malformed seminiferous cords, particularly adjacent to the tunica albuginea, with obvious thickening of the basement membranes (Fig. 1D). At an ultrastructural level, it was found that basal laminar components (lamina lucida and lamina densa) of the basement membranes of seminiferous cords were conspicuously thickened (Supplementary Figure 3, see section on supplementary data given at the end of this article).

\section{Frequency of Leydig cell clusters}

Immunostaining of the GD19 testis for the Leydig cell-specific enzyme $3 \beta$-hydroxysteroid dehydrogenase $(3 \beta-H S D)$ allowed for the quantification of Leydig cells in clusters. There was a significant increase in clusters containing 2-5 Leydig cells in the interstitium of the GD19 testis following exposure to $10 \mathrm{mg}$ (Fig. 2A); the mean number of clusters per testis cross section containing 2-5 Leydig cells was 14 compared with nine for controls. The $100 \mathrm{mg}$ exposure caused a significant increase in the size of the Leydig cell clusters; the mean number of clusters per testis cross section containing $>5$ Leydig cells was 11 compared with three in controls. The number of these large clusters was also significantly increased in the testes following the $10 \mathrm{mg}$ exposure, with an average of seven compared with three for control testes. Relatively few clusters were observed in cross sections of testes from controls (Fig. 2B), and those that were evident were predominantly 2-5 cell clusters. By contrast, the increase in clusters after exposure to $10 \mathrm{mg}$ was evident (Fig. 3C), and with $100 \mathrm{mg}$ exposure most of the clusters were quite large. These large clusters typically contained 20-50 Leydig cells.

\section{Decreased testosterone production}

A single GD19 testis from a control male produced an average of $15 \mathrm{ng}$ of testosterone over the course of a $3 \mathrm{~h}$ incubation with LH stimulation (Fig. 3). While there was no decrease in the ability of the testes from male offspring exposed to $10 \mathrm{mg}$ to produce testosterone, it was significantly reduced in males exposed to $100 \mathrm{mg}$, with only 9 ng testosterone produced during the incubation.

\section{Changes in the testis proteome}

The expression of 23 different proteins in the GD19 testis proteome was significantly altered at both 10 and $100 \mathrm{mg}$ exposures (Fig. 4 and Table 1). Those proteins which proved to be significantly correlated with treatment or the altered endpoints (viz., testosterone production and Leydig cell clustering) are shown in red in Fig. 4 and are indicated in bold in Table 1. Of the
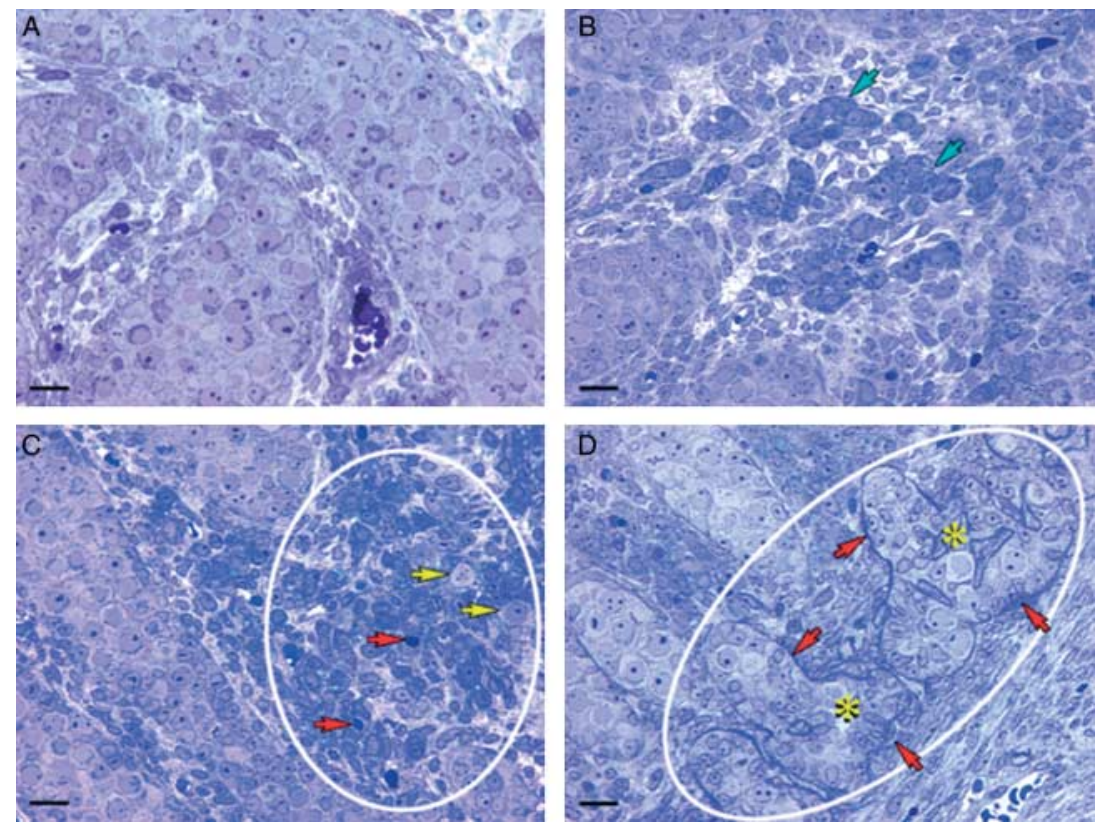

Figure $1(A, B, C$ and D) Photomicrographs depicting histological changes in the GD19 testis subsequent to DEHP exposure from GD13-GD19. (A) Image of the testis from a control fetus. (B) Leydig cells in testis in the $10 \mathrm{mg}$ exposure group begin to form clusters (cyan arrows). Most of these clusters contain 2-5 contiguous Leydig cells. (C) Leydig cell clusters in testes in the $100 \mathrm{mg}$ group are considerably larger. On occasion gonocytes (yellow arrows) can be observed in the interstitial space along with extravasated erythrocytes and what appear to be erythrophagosomes (red arrows). (D) Dysgenetic seminiferous cords in testes in the $100 \mathrm{mg}$ exposure group (asterisks). Note thickening of the basement membranes surrounding these cords (red arrows). Magnification bars $=20 \mu \mathrm{m}$. 

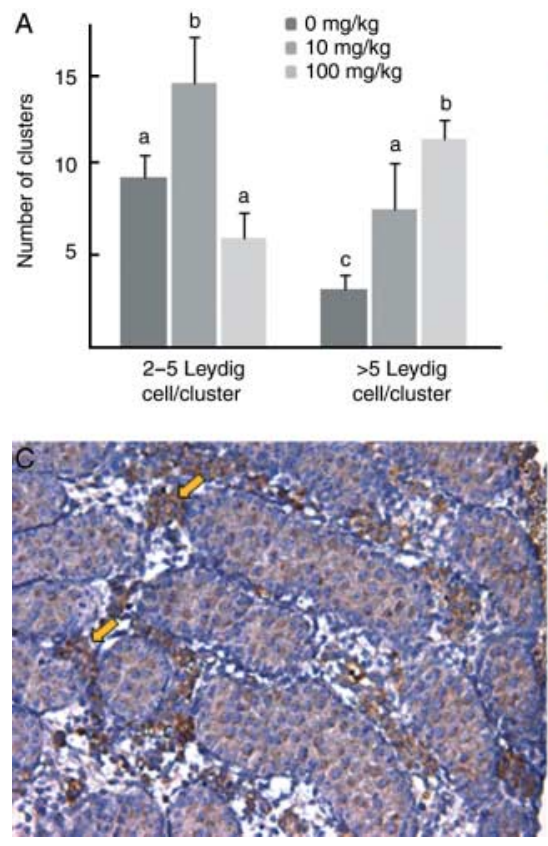
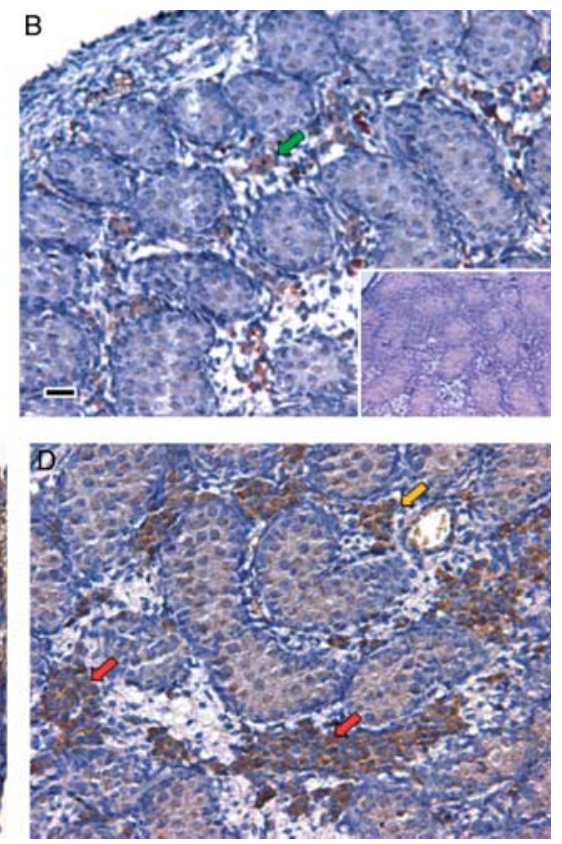

Figure 2 (A) Data showing frequency of Leydig cell clusters expressed as the mean number observed in a testis cross section (mean \pm s.E.M., $n=8$ males/treatment group; ${ }^{a, b, c}$ denote significance at $P<0.05)$. Clusters were classified as those containing $2-5$ contiguous Leydig cells (small clusters) and those containing more than five Leydig cells (large clusters). Note the significant increase in small cluster following exposure to $10 \mathrm{mg}$ and the significant increase in large clusters following exposure to $100 \mathrm{mg}$. (B) A GD19 control testis immunostained for $3 \beta-H S D$; Leydig cells are clearly indicated (green arrow). (C) Testes in the $10 \mathrm{mg}$ group showed a dramatic increase in small Leydig cell clusters (orange arrows). (D) The Leydig cell clusters in testes in the $100 \mathrm{mg}$ group were noticeably large (red arrows). Magnification bar shown in $(A)=20 \mu \mathrm{m}$.
23 different proteins identified, all but four were downregulated. Interestingly, three of the four that were upregulated were correlated with and predictive of certain endpoints (Table 2). These three proteins were heat shock $71 \mathrm{kDa}$ protein (HSPA8), spermadine synthase (SRM), and 14-3-3 epsilon (YWHAE). Of the 19 that were downregulated, four proteins - stressinduced phosphoprotein 1 (STIP1), heat shock protein 90 kDa (HSP90B1), heat shock protein 75 kDa (TRAP1), and dihydropyrimidinase-related protein 2 (DPYL2) were correlated with and predictive of certain endpoints.

We confirmed the upregulation of HSPA8 and YWHAE by both western blotting (Fig. 5) and immunohistochemistry (Fig. 6). Immunostaining for HSPA8 was increased in blots of the GD19 testis extract at both 10 and $100 \mathrm{mg}$ exposures. Similarly, immunostaining for YWHAE was increased at both dose levels of DEHP. While we did not identify a significant change in the expression of P450scc (or CYP11A1) at both 10 and $100 \mathrm{mg}$ exposures, there appeared to be a slight decrease in immunostaining for CYP11A1 in extracts of testes exposed to $100 \mathrm{mg}$. Immunohistochemical staining of the GD19 testis for both HSPA8 and YWHAE also confirms an increase in the expression of these two proteins following exposure to $10 \mathrm{mg}$ (Fig. 6). While inconclusive, the greatest increase in immunostaining appears to reside within the fetal Leydig cells.

\section{Correlations and predictivity}

There were five proteins that were significantly $(P<0.05)$ correlated with treatment, i.e. exposure to DEHP (Table 2). These were HSPA8, SRM, TRAP1, YWHAE, and STIP1. Three of these-HSPA8, TRAP1, and YWHAE
- were significantly correlated with the decreased capacity of the DEHP-exposed GD19 testis to produce testosterone when stimulated with $\mathrm{LH}$. Two additional proteins - DPYL2 and HSP90B1 - were found to be significantly correlated with the formation of small clusters containing 2-5 Leydig cells. The three proteins that were significantly correlated with the formation of the large clusters containing greater than five Leydig cells were HSPA8, SRM, and YWHAE. It is not surprising that two of these proteins - HSPA8 and YWHAE - were also correlated, albeit inversely, with testosterone production as the correlation between testosterone production and large clusters of Leydig cells were highly significant $(P<0.02)$.

Discriminant analysis revealed which proteins were predictive for treatment or a specific measured endpoint (Table 2). HSPA8 and YWHAE were found to be predictive of treatment and each measured endpoint.

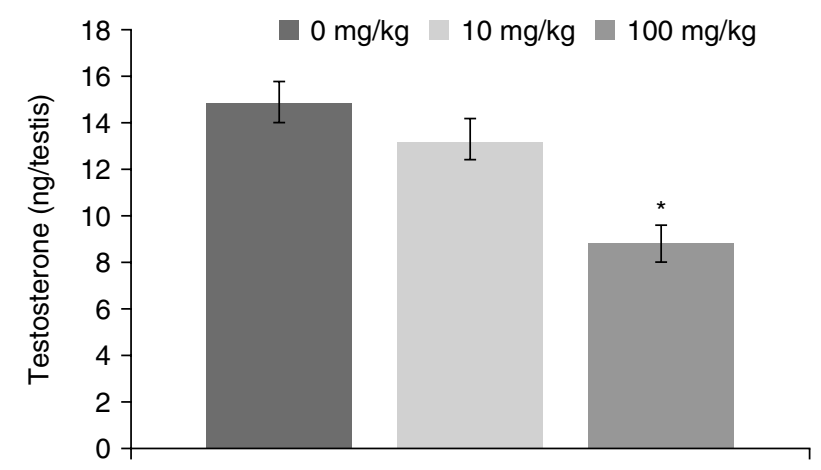

Figure 3 Testosterone production by the GD19 testis over $3 \mathrm{~h}$ while challenged with maximal (100 ng/ml) LH stimulation. The observed decrease in testosterone production by testes exposed to $100 \mathrm{mg}$ $\mathrm{DEHP} / \mathrm{kg}$ was highly significant $\left({ }^{*} P<0.0001\right)$; mean \pm s.E.M., $n=16$. 


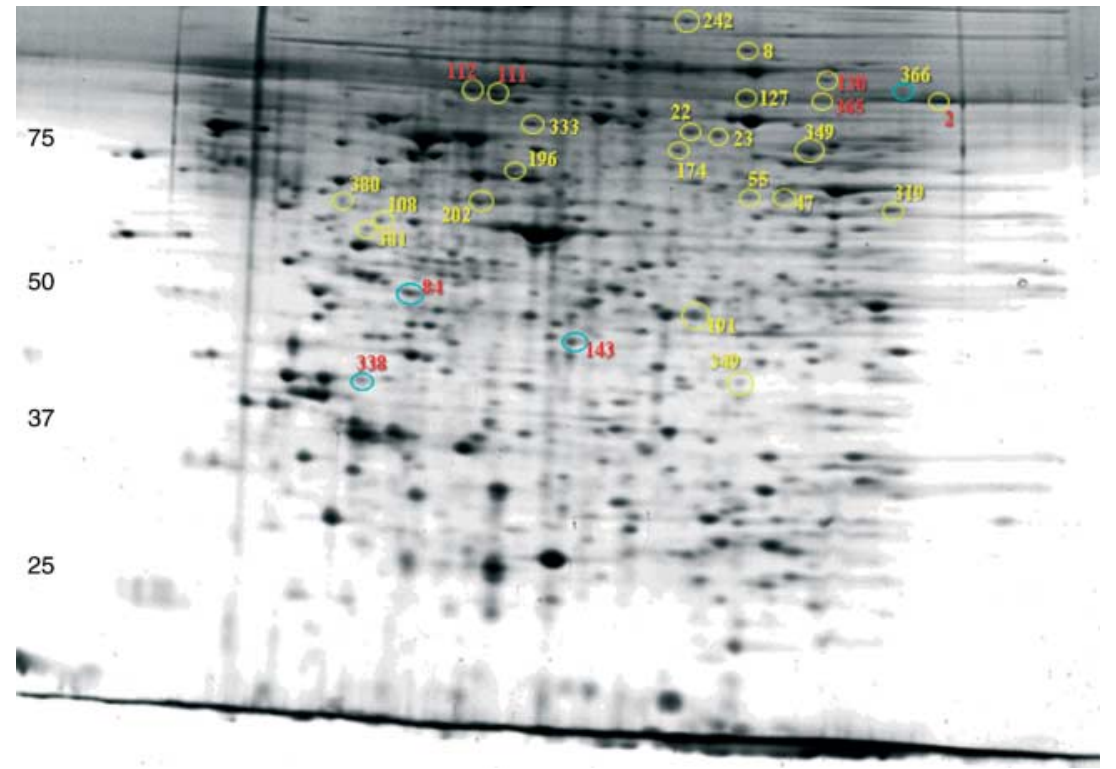

Figure 4 Two-dimensional gel profile of the GD19 testis proteome. Proteins which were significantly altered by both the 10 and $100 \mathrm{mg}$ exposures are indicated. Proteins whose expression was upregulated are circled in cyan, all other proteins were downregulated. Proteins that were either correlated with and/or predictive of treatment, testosterone production, or Leydig cell clustering are indicated by the red numbers.
When TRAP1 was used along with HSPA8 and YWHAE, 100,75 , and 100 percent of the animals in control, 10 and $100 \mathrm{mg}$ treatment groups were correctly classified (Table 3). When HSP90B1 was used along with HSPA8 and YWHAE, 100, 75, and 100 percent of the testes in control, 10 and $100 \mathrm{mg}$ treatment groups were correctly classified based on the frequency of small Leydig cell clusters. Interestingly, DPYL2, which was highly significant when correlated with small Leydig cell clusters $(P<0.0005)$, was actually predictive of the formation of large Leydig cell clusters. When used together with HSPA8 and YWHAE, 100, 100, and 75 percent of the testes in the control, 10 and $100 \mathrm{mg}$ treatments were classified correctly based on the frequency of large Leydig cell clusters. There was less certainty predicting decreased steroidogenic capacity of the fetal Leydig cell to produce testosterone; HSPA8 and YWHAE provided the best result. These two proteins correctly predicted 100 percent of the incubations of testes from controls and $10 \mathrm{mg}$ exposure but only half of the incubations of testes from the $100 \mathrm{mg}$ exposure.

\section{Pathway analysis}

Ingenuity Pathway Analysis software was used to identify pathway networks. Analysis of all 23 proteins whose expression was altered significantly by both levels of DEHP exposure resulted in two pathway networks. One included 17 of the 23 identified proteins (Supplementary Figure 4, see section on supplementary data given at the end of this article). Interestingly, many of these proteins were shown to interact with one another. The second network contained the remaining six proteins (Supplementary Figure 5, see section on supplementary data given at the end of this article). In this network, none of the proteins interacted with one another. A third network (Supplementary Figure 6, see section on supplementary data given at the end of this article) contained the seven proteins that were correlated with and predictive of DEHP treatment, small and large clusters of fetal Leydig cells, and the capacity of the fetal Leydig cell to produce testosterone. Figure 7 is an attempt to depict the relationships of these proteins as shown in the network. This isolated pathway network reveals that two of the seven proteins (i.e. YWHAE and STIP1) are known to interact directly with HSPA8. To our surprise, estradiol was identified as being related to the expression of all seven proteins. All but two of the seven proteins are known to have a direct relationship with estradiol; DYPL2 and TRAP1 appear regulated subsequent to estradiol-mediated regulation of amyloid precursor protein (APP) and proto-oncogene c-myc (MYC) respectively.

\section{Estradiol in the GD19 fetus}

Based on the fact that estradiol was at the focal point of the pathway network for proteins correlated with and predictive of various endpoints, we conducted a followup study in an attempt to identify any alteration in estradiol following DEHP exposure. Blood plasma from GD19 males exposed to $100 \mathrm{mg}$ DEHP was found to have significantly increased levels of estradiol compared with control males; 118 vs 68 pg/ml (Fig. 8). There was no difference in estradiol levels between $100 \mathrm{mg}$ females and control females (data not shown).

\section{Discussion}

We identified novel proteins involved with the onset of dysgenesis of the fetal rat testis and altered capacity of the fetal Leydig cell to produce testosterone following 
Table 1 Proteins found to be significantly down- or up-regulated following both 10 and $100 \mathrm{mg} / \mathrm{kg}$ DEHP exposures.

\begin{tabular}{|c|c|c|c|c|c|c|c|c|c|}
\hline \multirow[b]{2}{*}{ Spot } & \multirow[b]{2}{*}{ Symbol } & \multirow[b]{2}{*}{$\begin{array}{l}\text { Accession } \\
\text { numbers }\end{array}$} & \multirow[b]{2}{*}{ Protein name } & \multirow[b]{2}{*}{$\begin{array}{c}\text { Protein } \\
\mathrm{MW}(\mathrm{kDa})\end{array}$} & \multirow[b]{2}{*}{$\begin{array}{c}\text { Percent } \\
\text { coverage }\end{array}$} & \multicolumn{3}{|c|}{ Dose } & \multirow[b]{2}{*}{$\begin{array}{l}\text { Molecular } \\
\text { function }\end{array}$} \\
\hline & & & & & & 0 & 10 & 100 & \\
\hline 2 & $\underline{\text { STIP1 }}$ & Q3ZCU9 & $\begin{array}{l}\text { Stress-induced- } \\
\text { phosphoprotein } 1\end{array}$ & 63 & 66 & 100 & $58^{\mathrm{a}}$ & 52 & Protein-protein binding \\
\hline 8 & SYG & Q510G4 & Glycyl t-RNA synthetase & 72 & 15 & 100 & 56 & 66 & Protein biosynthesis \\
\hline 22 & LMAN1 & Q62902 & Lectin mannnose binding 1 & 55 & 20 & 100 & 61 & 71 & Protein transport \\
\hline 23 & PDIA3 & P11598 & Protein disulfide-isomerase A3 & 57 & 60 & 100 & 67 & 71 & Cellular redox homeostasis \\
\hline 47 & ENO1 & P04764 & Alpha enolase & 47 & 29 & 100 & 60 & 60 & $\begin{array}{l}\text { Glycolysis/plasminogen } \\
\text { activation }\end{array}$ \\
\hline 55 & ENO1 & P04764 & Alpha enolase & 47 & 37 & 100 & 78 & 73 & $\begin{array}{l}\text { Glycolysis/plasminogen } \\
\text { activation }\end{array}$ \\
\hline 84 & $\underline{\text { HSPA8 }}$ & P63018 & Heat shock protein $71 \mathrm{kDa}$ & 71 & 38 & 100 & 143 & 162 & $\begin{array}{l}\text { Chaperone/transcriptional } \\
\text { repressor }\end{array}$ \\
\hline 108 & ACTG & P63259 & Actin, cytoplasmic 2 & 42 & 33 & 100 & 40 & 37 & $\begin{array}{l}\text { Responder to calcium/ATP } \\
\text { binding }\end{array}$ \\
\hline 111 & $\underline{\text { HSP90B1 }}$ & Q66HD0 & $\begin{array}{l}\text { Heat shock protein } 90 \mathrm{kDa} \text {, } \\
\text { subunit } 1\end{array}$ & 90 & 7 & 100 & 53 & 59 & $\begin{array}{l}\text { Chaperone in the } \\
\text { endoplasmic reticulum }\end{array}$ \\
\hline 112 & HSP90B1 & Q66HD0 & $\begin{array}{l}\text { Heat shock protein } 90 \mathrm{kDa} \text {, } \\
\text { subunit } 1\end{array}$ & 90 & 7 & 100 & 51 & 50 & $\begin{array}{l}\text { Chaperone in the } \\
\text { endoplasmic reticulum }\end{array}$ \\
\hline 127 & $\underline{\mathrm{TCP} 1}$ & P28480 & $\begin{array}{l}\text { T complex protein } 1 \text { subunit } \\
\text { alpha }\end{array}$ & 60 & 40 & 100 & 62 & 60 & $\begin{array}{l}\text { Chaperone involved in } \\
\text { protein folding }\end{array}$ \\
\hline 130 & TRAP1 & Q5XHZ0 & $\begin{array}{l}\text { Heat shock protein } 75 \mathrm{kDa} \text {, } \\
\text { Mito. }\end{array}$ & 74 & 26 & 100 & 68 & 58 & $\begin{array}{l}\text { Chaperone involved in } \\
\text { protein folding }\end{array}$ \\
\hline 143 & SRM & Q99MI5 & Spermadine synthase & 34 & 18 & 100 & 132 & 140 & Spermadine biosynthesis \\
\hline 174 & $\begin{array}{l}\overline{\text { ATP6V1- }} \\
\text { B2 }\end{array}$ & P62815 & $V$ type proton ATPase subunit B & 57 & 12 & 100 & 49 & 47 & $\begin{array}{l}\text { Hydrogen ion transport/ } \\
\text { ATPase activity }\end{array}$ \\
\hline 191 & RPLPO & P19945 & $60 S$ acidic ribosomal protein P0 & 34 & 34 & 100 & 67 & 63 & Translational elongation \\
\hline 196 & PDIA6 & Q63081 & Protein disulfide isomerase A6 & 46 & 33 & 100 & 78 & 70 & $\begin{array}{l}\text { Chaperone/platelet } \\
\text { aggregation }\end{array}$ \\
\hline 202 & ССT5 & Q68FQ0 & $\begin{array}{l}\text { T complex protein } 1 \text { subunit } \\
\text { epsilon }\end{array}$ & 59 & 23 & 100 & 71 & 76 & $\begin{array}{l}\text { Chaperone involved in } \\
\text { protein folding }\end{array}$ \\
\hline 242 & GSTM4 & P08009 & Glutathione S-transferase & 26 & 6 & 100 & 72 & 73 & $\begin{array}{l}\text { Conjugation of reduced } \\
\text { glutathione }\end{array}$ \\
\hline 319 & TUFM & P49411 & Elongation factor Tu, Mito. & 45 & 67 & 100 & 78 & 74 & Translation of proteins \\
\hline 333 & TRAP1 & Q5XHZ0 & Heat protein $75 \mathrm{kDa}$, Mito & 74 & 27 & 100 & 62 & 67 & Chaperone/ATPase activity \\
\hline 338 & YWHAE & P62260 & 14-3-3 epsilon & 32 & 32 & 100 & 142 & 177 & $\begin{array}{l}\text { Signal transduction via } \\
\text { protein binding }\end{array}$ \\
\hline 349 & ССТ2 & Q5XIM9 & $\begin{array}{l}\text { T complex protein } 1 \text { subunit } \\
\text { beta }\end{array}$ & 57 & 57 & 100 & 80 & 75 & $\begin{array}{l}\text { Chaperone involved in } \\
\text { protein folding }\end{array}$ \\
\hline 365 & $\underline{\text { DPYL2 }}$ & P47942 & $\begin{array}{l}\text { Dihydropyrimidinase-related } \\
\text { protein } 2\end{array}$ & 62 & 28 & 100 & 70 & 76 & $\begin{array}{l}\text { Differentiation/cell } \\
\text { migration }\end{array}$ \\
\hline 366 & RPL13A & Q5RKI0 & WD repeat containing protein 1 & 66 & 26 & 100 & 134 & 152 & Disassembly of actin \\
\hline 380 & VIM & P31000 & Vimentin & 54 & 24 & 100 & 59 & 74 & $\begin{array}{l}\text { Intermediate filament of } \\
\text { cytoskeleton }\end{array}$ \\
\hline 381 & RPSA & P38983 & $40 \mathrm{~S}$ ribosomal protein SA & 33 & 33 & 100 & 73 & 67 & $\begin{array}{l}\text { Cell surface receptor for } \\
\text { laminin/morphogenesis }\end{array}$ \\
\hline
\end{tabular}

Statistical results represent the analysis of 16 I per treatment group $(n=16)$; one testis from four GD19 males pooled and extracted/litter.

${ }^{a}$ The background-corrected, integrated optical density of each spot was averaged within group and expressed as percent of control. The symbols of proteins that were found to be significantly $(P<0.05)$ correlated with and/or predictive of treatment or measured endpoints (bold and underlined).

exposure to lower more relevant DEHP exposures. We first correlated proteins in the fetal testis proteome that were significantly altered at both 10 and $100 \mathrm{mg}$ exposures of the animal, as well as to the endpoints we quantified, i.e. Leydig cell clusters and altered testosterone production. Next, discriminant analysis identified which of the correlated proteins were predictive; these proteins were subjected to pathway analysis. The underlying goal of this approach was to identify novel predictive biomarkers in adverse outcome pathways associated with DEHP exposure. Two proteins, HSPA8 and YWHAE were predictive of both an increased frequency in Leydig cell clusters and reduced capacity to produce testosterone. Estradiol was linked to the observed alterations in these proteins. These two new proteins and estradiol may be candidates for new assays developed to screen for early onset testicular dysgenesis.

Previous work suggested that clustering of fetal rat Leydig cells occurs following in utero exposure to $10 \mathrm{mg}$ DEHP/kg from GD2-GD20 (Lin et al. 2008). Testosterone content in the fetal testis was not altered until a $750 \mathrm{mg} / \mathrm{kg}$ exposure was reached. Herein we also observed significant Leydig cell clustering following in utero exposure to $10 \mathrm{mg}$ from GD13-GD19 assessed by both light microscopy and immunohistochemical staining for $3 \beta-\mathrm{HSD}$. Both small and large clusters of 
Table 2 Proteins determined to be correlated and/or predictive of treatment and quantified endpoints.

\begin{tabular}{|c|c|c|c|c|c|c|c|c|}
\hline \multirow[b]{2}{*}{ Treatment } & \multirow[b]{2}{*}{ HSPA8 } & \multicolumn{3}{|c|}{ Correlated } & & \multicolumn{3}{|c|}{ Predictive } \\
\hline & & SRM & TRAP1 & YWHAE & \multirow[t]{4}{*}{ STIP1 } & HSPA8 & TRAP1 & YWHAE \\
\hline Testosterone & HSPA8 & TRAP1 & YWHAE & & & HSPA8 & YWHAE & \\
\hline Small LC clusters & DPYL2 & HSP90B1 & & & & HSPA8 & HSP90B1 & YWHAE \\
\hline Large LC clusters ${ }^{\mathrm{a}}$ & HSPA8 & SRM & YWHAE & & & HSPA8 & DPYL2 & YWHAE \\
\hline
\end{tabular}

${ }^{\mathrm{a} C}$ Correlation between large clusters and $\mathrm{T}(P<0.02)$.

Leydig cells were more frequent at $10 \mathrm{mg}$ than in control testes. At $100 \mathrm{mg}$ there was a substantial increase in large clusters as the frequency of small clusters decreased to that of controls. Presumably, the return in small clusters to a control frequency reflects the transition and/or further aggregation of many small clusters to large clusters as exposure level increased.

Light microscopy revealed other facets of dysgenesis in the fetal testis with exposure to $100 \mathrm{mg}$ DEHP. Gonocytes were observed in the interstitium along with what appeared to be erythrophagosomes resulting from extravasated erythrocytes. In addition, misshapen seminiferous cords/tubules around the periphery of the fetal testis displayed a marked thickening of the basement membranes. Multinucleated germ cells were first observed following in utero exposure to $750 \mathrm{mg}$ DEHP/kg (Gray et al. 2000, Parks et al. 2000) and later in both rats and mice exposed in utero to $250-500 \mathrm{mg}$ DBP/kg (Gaido et al. 2007). Leydig cells have been observed in newly formed tubules, along with Sertoli cells in interstitial spaces following $500 \mathrm{mg} \mathrm{DBP} / \mathrm{kg}$ (Mahood et al. 2006). Gray et al. (2000) documented extravasated erythrocytes and erythrophagosomes in the interstitium at $750 \mathrm{mg} D E H P / \mathrm{kg}$, but the presence of germ cells in the interstitium with $100 \mathrm{mg} / \mathrm{kg}$ phthalate exposure in utero has not been reported, nor has the appearance of erythrophagosomes or aberrant basement membranes of dysgenetic seminiferous tubules at this relatively low exposure level.

While testosterone production by the fetal testis in vivo is independent of $\mathrm{LH}$ (Huhtaniemi \& Pelliniemi 1992), the fetal Leydig cell does possess LH receptors as early as GD16 (Zhang et al. 1994). As we tested lower exposures than those usually studied, we challenged the GD19 Leydig cell with LH during a $3 \mathrm{~h}$ incubation to determine whether the Leydig cell's 'capacity' to produce testosterone was compromised. Our results demonstrate that while the decrease in the capacity of the GD19 testis to produce testosterone following exposure to $10 \mathrm{mg}$ was not significant, the decrease following exposure to $100 \mathrm{mg}$ was significant. A significant decrease in testosterone production by the fetal testis ex vivo at an exposure of $100 \mathrm{mg}$ has not been reported. That the increased formation of Leydig cell clusters at $10 \mathrm{mg}$ was significant and the decrease in testosterone production ex vivo was not significant, demonstrates that dysgenesis within the fetal testis precedes compromised testosterone production. A recent study has shown that multiple phthalates begin to compromise testosterone production by the unstimulated fetal testis ex vivo at $300 \mathrm{mg} / \mathrm{kg}$ (Hannas et al. 2011). Thus, the dysgenesis which results from the $10 \mathrm{mg}$ exposure does indeed precede the dysfunction of the fetal Leydig cell ex vivo as well as in vivo.

We speculate that once aggregated, the fetal Leydig cells become dysfunctional, which results in their decreased ability to produce testosterone. Data from recent studies with the fetal human testis tend to support this notion. When fetal human testis explants were cultured in vitro with MBP, neither a decrease in testosterone production nor any aggregation of Leydig cells was observed (Hallmark et al. 2007). By contrast Leydig cell aggregation and reductions in testosterone production were observed in similarly cultured fetal rat testis explants. The ability to produce testosterone by human or rat fetal testis explants was studied in castrate nude mice that were exposed to DBP for 2 weeks subsequent to the grafting (Mitchell et al. 2012). Serum testosterone levels were unchanged in mice with human testis grafts but were significantly decreased in mice containing rat testis grafts. The histology of the human fetal testis graft following DBP exposure has not been reported; we surmise that there will be no significant aggregation of Leydig cells in the exposed human testis explants.



Figure 5 Western blot demonstrating the increased expression of both HSPA8 and YWHAE following DEHP exposure. P450scc (CYP11A1) was evaluated to confirm the absence of altered expression at both 10 and $100 \mathrm{mg}$ exposures. Samples from $3 \mathrm{I}$ were evaluated, one shown for representation. 



Figure 6 Immunohistochemical staining for HSPA8 and YWHAE in the GD19 testis. (A) In control testes HSPA8 is localized (brown reaction product) in germ cells in the seminiferous tubules and throughout the entire Leydig cell in the interstitium (cyan arrow). (B) In testes in the $10 \mathrm{mg}$ exposure group immunostaining of the Leydig cells is visibly increased (cyan arrow). (C) Like HSPA8, YWHAE is localized in control testes in both germ cells and interstitial Leydig cells. (D) And like HSPA8, the increase in immunostaining in testes in the $10 \mathrm{mg}$ exposure group is more pronounced in the Leydig cell. Magnification bar shown in $(\mathrm{A})=20 \mu \mathrm{m} . n=8$ males examined/treatment group.
In an attempt to better understand the molecular pathways involved in DEHP-induced Leydig cell clustering and altered testosterone production, we relied on our quantitative proteomic evaluation of the GD19 testis. Of the 23 different proteins that were altered significantly at both exposure levels, not one was previously considered to be pivotal to steroidogenesis. Before proceeding to discriminant and pathway analyses on these newly identified proteins, we probed western blots of extracts from control and DEHP-exposed testes with P450scc (CYP11A1) to confirm the absence of altered expression at both 10 and $100 \mathrm{mg}$ exposures. This protein was selected, as several studies have demonstrated decreased gene expression of P450scc and other steroidogenic molecules following in utero exposure to phthalates at doses as low as $100 \mathrm{mg}$ (Shultz et al. 2001, Lehmann et al. 2004, Hannas et al. 2011). We observed no decrease across the DEHP exposures; a slight decrease at $100 \mathrm{mg}$ was suggested. This is consistent with previous results reporting no decrease in expression of P450scc protein (Lehmann et al. 2004) or its activity (Lin et al. 2008) until at least a $500 \mathrm{mg}$ exposure was reached. Obviously alterations in gene expression occur at lower exposures than those resulting in proteomic changes.

Five proteins were correlated with exposure to DEHP, i.e. HSPA8, SRM, TRAP1, YWHAE, and STIP1. STIP1 is a co-chaperone homologous to heat shock proteins 70 and 90. Its expression was previously shown to be altered in MEHP-exposed mouse testis (Mizrak et al. 2006). In addition to HSPA8 and YWHAE, heat shock protein $75 \mathrm{kDa}$ (TRAP1) was predictive of treatment. Trap1 is another heat shock protein shown to protect against ischemic injury (Voloboueva et al. 2008). The decrease in this protein may be associated with the observed extravasated erythrocytes resulting from damage to vessel walls (hemorrhage) and consequent formation of erythrophagosomes observed at $100 \mathrm{mg}$.

Five proteins were correlated with the increased frequency of Leydig cell clusters following DEHP exposure, i.e. DPYL2, HSP90B1, HSPA8, SRM, and YWHAE. DPYL2 is involved with differentiation and migration of cells (Rozhkova et al. 2011) consistent with a role in clustering of Leydig cells. Spermadine, the product of SRM, is important in fetal development, stages of spermatogenesis and steroidogenesis (Lefevre et al. 2011). HSP90B1 was recently associated with alterations in sperm chromatin integrity following exposure to chemotherapeutic agents (Maselli et al. 2012) and found to be predictive of small clusters. Interestingly, while DPYL2 was not correlated with the

Table 3 Classification of treatment, Leydig cell clusters, and testosterone production by discriminant analysis.

\begin{tabular}{lc}
\hline Predictors & \% Correctly classified \\
\hline HSPA8, TRAP1, YWHAE & \\
Treatment & 100 \\
Control & 75 \\
$10 \mathrm{mg} / \mathrm{kg}$ & 100 \\
$100 \mathrm{mg} / \mathrm{kg}$ & \\
HSPA8, HSP90B1, YWHAE & \\
Small Leydig cell clusters & 100 \\
Control & 75 \\
$10 \mathrm{mg} / \mathrm{kg}$ & 100 \\
$100 \mathrm{mg} / \mathrm{kg}$ & \\
HSPA8, DPYL2, YWHAE & \\
Large Leydig cell clusters & 100 \\
Control & 100 \\
$10 \mathrm{mg} / \mathrm{kg}$ & 75 \\
$100 \mathrm{mg} / \mathrm{kg}$ & \\
HSPA8 and YWHAE & \\
Testosterone production & 100 \\
Control & 100 \\
$10 \mathrm{mg} / \mathrm{kg}$ & 50 \\
$100 \mathrm{mg} / \mathrm{kg}$ &
\end{tabular}




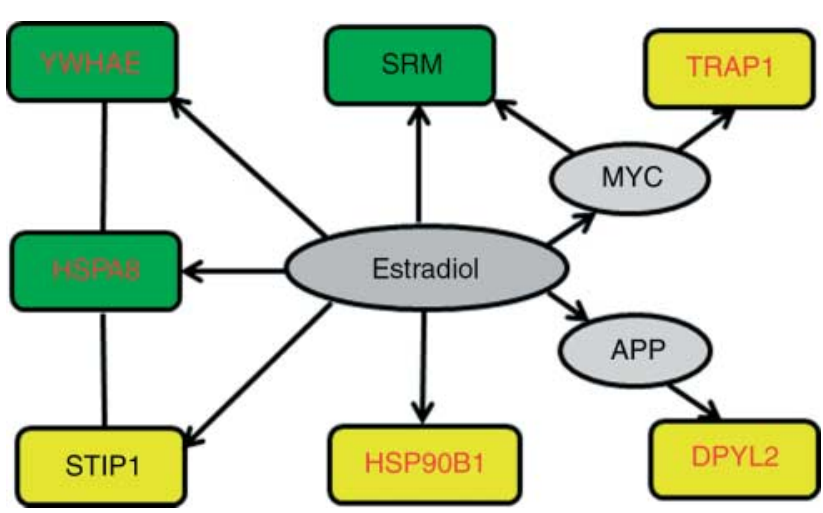

Figure 7 Diagram depicting the pathways common to those proteins that were correlated with and/or predictive of endpoints (i.e. treatment, testosterone production, Leydig cell clustering). Proteins whose expression was increased with DEHP exposure, i.e. heat shock protein 71 (HSPA8), spermadine synthase (SRM), and 14-3-3 epsilon (YWHAE) are shown in green boxes whereas proteins whose expression was decreased with exposure, i.e. stress induced protein 1 (STIP1), heat shock protein 90 subunit 1 (HSP90B1), dihydropyrimidinase-related protein 2 (DPYL2), and heat shock protein 75 kDa (TRAP1) are shown in yellow boxes. Proteins that are predictive of particular endpoints appear in red. YWHAE and STIP1 are shown to interact directly with HSPA8 (solid lines). Estradiol was identified as central to the regulation of all seven proteins. The expression of DPYL2 appears to be indirectly regulated by estradiol via amyloid precursor protein (APP) and the expression of TRAP1 is indirectly regulated by estradiol via MYC.

formation of large Leydig cell clusters, it was predictive of these clusters. Heat shock protein $71 \mathrm{kDa}$ (HSPA8) and 14-3-3 epsilon (YWHAE) were predictive of both small and large Leydig cell clusters. HSPA8 is now known as one of the pivotal signaling proteins during gonadal development (Wilhelm et al. 2006). YWHAE is involved in signal transduction consequent to phosphoserine/ threonine binding and pivotal to proper neuronal migration and brain development (Toyo-oka et al. 2003).

Three proteins were correlated with decreased capacity of the LH-stimulated fetal Leydig cell to produce testosterone following DEHP exposure, i.e. TRAP1, HSPA8, and YWHAE. TRAP1 was correlated with testosterone production by the $\mathrm{LH}$-stimulated GD19 fetal testis, but only HSPA8 and YWHAE proved predictive for testosterone production. And, while this combination predicted 100 percent of the incubations from control and $10 \mathrm{mg}$ testes correctly, only 50 percent of the $100 \mathrm{mg}$ testes were classified correctly. We suspect that a protein(s) needed to predict the significant decrease in the capacity of the GD19 testis to produce testosterone at $100 \mathrm{mg}$ is (are) only significantly altered in $100 \mathrm{mg}$ dose extracts. This further supports the notion that DEHP-induced testicular dysgenesis precedes alterations in testosterone production; as clusters become larger, additional protein(s) become linked to compromised testosterone synthesis.

The pathway network created for the seven proteins that were correlated with and predictive of DEHP exposure and the measured endpoints revealed two direct interactions. HSPA8 has been shown to bind to both YWHAE (Ballif et al. 2006) and STIP1 (Odunuga et al. 2003). Surprisingly, the focal point in the pathway network clearly was estradiol. The expression of HSPA8 itself is known to be increased by estradiol, as it was following DEHP exposure (Mercier et al. 2009). YWHAE which was upregulated by DEHP exposure is also increased by estradiol (Thompson et al. 2002). Based on immunohistochemical staining, both HSPA8 and YWHAE appeared to have increased expression in the fetal Leydig cells in both 10 and 100 mg testes. The third predictive upregulated protein of the seven was SRM, also known to be regulated by estradiol (Kapyaho et al. 1980); SRM is also regulated by MYC (Guo et al. 2000) which is part of the pathway network.

HSP90B1, another heat shock protein altered in this study, is also regulated by estradiol (Papacontstantinou et al. 2002). While normally estrogen might be expected to increase HSP90B1, DEHP exposure resulted in a significant decrease in HSP90B1. Both HSP70 and 90 are known to complex with estrogen receptor (ER) to form a stable, high affinity estradiol-binding state (Whitesell \& Lindquist 2005). With DEHP exposure, HSP90B1 may be altering estradiol expression by virtue of decreased levels in the ER-HSP complex. The remaining proteins in the pathway network, i.e. STIP1, DPYL2, and TRAP1 were also decreased by DEHP exposure. STIP1 has been shown to be directly regulated by estradiol (Watanabe et al. 2003), while DPYL2 is dependent on estradiolmediated App expression (Manthey et al. 2001). TRAP1 expression is regulated by MYC (McConnell et al. 2003), which in turn is known to be regulated by estradiol (Wang et al. 2011). ER $\alpha$ (now referred to as ESR1) appears to mediate this regulation (Duplessis et al. 2011). While we only localized the expression of HSPA8 and YWHAE, the two proteins that were predictive of exposure and each quantified endpoint, we suspect the expression of some

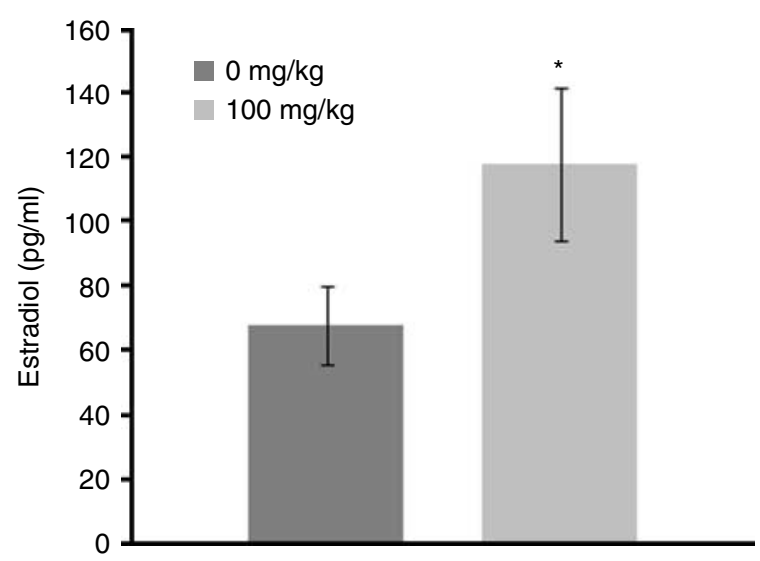

Figure 8 Plasma estradiol concentrations in GD19 males. The observed increase in the estradiol level in males exposed to $100 \mathrm{mg}$ DEHP from GD13 to GD19 was significant $(* P<0.05)$ compared with control males; mean \pm s.E.M., $n=7$ males/group. 
of the other five proteins that may be changing in the fetal Leydig cell as well.

While estradiol's involvement in this pathway network was unexpected, it is well known that increased exposure to estradiol adversely affects male reproductive development (Delbes et al. 2006, Howdeshell et al. 2007) including cryptorchidism, germ cell atypia, thickening of basement membranes of seminiferous tubules, and dysplastic adenomyotic lesions in the epididymis (Veeramachaneni et al. 1988, Veeramachaneni 2006). Moreover, exogenous administration of androgen to pregnant females exposed to diethylstilbestrol (DES) fails to prevent DES-induced cryptorchidism (Hutson et al. 1990). ESR1 is a major contributor to estrogen-mediated dysgenesis of the fetal testis and cryptorchidism (Cederroth et al. 2007). Exogenous estradiol has been reported to decrease testosterone production by GD16 and GD21 Leydig cells (Delbes et al. 2006). This is also apparently mediated via ESR 1 , as fetal testes from $E R \alpha-k n o c k o u t$ mice produce significantly more testosterone than wild type mice under both LH-stimulated and unstimulated conditions. ESR1 is expressed in the testis of mice and rats early in fetal development and has been localized in the Leydig cell (O'Donnell et al. 2001). Collectively, this suggests that DEHP exposure may increase levels of estradiol and/or increase the responsiveness of ESR1 to estradiol in the fetal rat testis. Given that DEHP has virtually no binding affinity for the ER (Blair et al. 2000), it is unlikely that DEHP binds ESR1 to activate signaling.

We sought to verify in a follow-up study, if there would be an increase in circulating estradiol in male fetuses exposed to 0 or $100 \mathrm{mg}$ from GD13-GD19. We were surprised to find that plasma estradiol levels were increased approximately twofold in males exposed to DEHP compared with control males. Future studies are needed to determine the source of the increased estradiol, i.e. increased aromatase activity in the fetal Sertoli cell, the fetal Leydig cell, or both cell types. Nonetheless, the increase in plasma estradiol following DEHP exposure is consistent with the above discussion and the notion that estradiol is pivotal to the observed dysgenesis of the fetal testis as well as early events resulting in decreased ability of the fetal Leydig cell to produce testosterone. In a previous study in which $10 \mathrm{mg}$ DEHP/kg was administered to rats from weaning until adulthood, Leydig cell hyperplasia was demonstrated (Akingbemi et al. 2004). In this study, Leydig cells purified from DEHP-treated animals were found to produce significantly less testosterone in response to LH. Interestingly, these Leydig cells produced increased levels of estradiol. Thus, DEHP may enhance aromatase activity in the fetal rat Leydig cell and/or Sertoli cell resulting in increased estradiol, ESR1-mediated dysgenesis, and ultimately compromised ability of Leydig cell to produce testosterone. However, aromatase activity need not necessarily be enhanced within the
Leydig cell for compromised testosterone production by estradiol. Indeed, both in vitro and in vivo exposures to estradiol have resulted in significantly decreased testosterone production (Delbes et al. 2006). Regardless, the compromise is thought to be mediated via ESR1. While fetal rat Leydig cells possess ESR1, the human fetal testis is devoid of ESR1 (Boukari et al. 2007). This may explain, in part, why DEHP exposure fails to alter testosterone production in human fetal testis (Mitchell et al. 2012).

In summary, lower DEHP exposures resulted in dysgenesis of the fetal rat testis, specifically clustering of the fetal Leydig cell, which preceded significant compromise in testosterone production. A comprehensive proteomic evaluation of the fetal testis revealed 23 individual proteins that were altered significantly by both DEHP exposures. With correlation and discriminant analyses, we determined that seven of these proteins were predictive of i) DEHP exposure, ii) increased frequency of both small and large Leydig cell clusters in the fetal testis, and iii) the capacity of the GD19 Leydig cell to produce testosterone when stimulated with LH. Pathway analysis and fetal plasma hormone data support the notion that the onset of dysgenesis in the fetal rat testis exposed to phthalates may be mediated by estradiol. The new predictive proteins may be used to develop new assays to screen for the onset of testicular dysgenesis. It remains to be determined if such assays would be applicable to detection of dysgenetic phenotypes in the human fetal testis.

\section{Materials and Methods}

\section{Animals and experimental design}

The study consisted of two replicate experiments. A total of 60 timed-pregnant Sprague-Dawley rats (Charles Rivers Laboratories, Inc., Durham, NC, USA) were allowed to acclimate for 1 week before the onset of dosing. The U.S. EPA NHEERL IACUC approved all procedures. Pregnant dams were housed individually under room conditions of $12 \mathrm{~h}$ light: $12 \mathrm{~h}$ darkness, $22 \pm 1{ }^{\circ} \mathrm{C}, 50 \% \pm 10 \%$ relative humidity.

For each experiment 30 dams were randomly assigned based on body weight ranking on GD11 to one of three treatment groups (control, $10 \mathrm{mg} \mathrm{DEHP/kg}$, and $100 \mathrm{mg} \mathrm{DEHP/kg}$ ) to provide a minimum of 8 I per treatment group. DEHP (SigmaAldrich) was diluted in corn oil and administered daily in the morning by oral gavage $(2 \mu \mathrm{l} / \mathrm{g}$ body weight) from GD13 until necropsy on GD19. Each of the two replicate experiments was performed in two randomized blocks over 2 consecutive days. Each block consisted of $4 \mathrm{I}$ per treatment group and for each litter, four males were randomly selected for testosterone, proteomics, and histology evaluations. For the entire study, each endpoint in each treatment group was represented by $16 \mathrm{I}$ (64 males). Thus, the entire study consisted of 48 I (192 males).

On the day of necropsy, the right testis of each selected male was fixed in either glutaraldehyde (two males/litter) for light and transmission electron microscopy or formaldehyde (two males/litter) for immunohistochemistry. The left testis of each male 
was incubated in medium to determine testosterone production (described below). After the incubation, the four testes per litter were pooled and frozen for subsequent extraction and proteomics. Thus, it was possible to correlate testosterone production and the proteins in the testis proteome on a litter basis. Moreover, data from each of the two testes chosen for $3 \beta$ HSD immunohistochemistry could be correlated with the testosterone produced by the contralateral testis in these males.

\section{Testosterone production by the GD19 testis}

The left testis from each of four males/litter was placed in a well of a 24-well culture plate in $1 \mathrm{ml}$ pre-warmed medium, Medium199 (Gibco, \#94-038DK), buffered with sodium bicarbonate, and supplemented with BSA $(0.2 \%)$, insulin-transferrin-selenium mix, sodium pyruvate, and non-essential amino acids. Immediately after the four testes/litter were plated, $100 \mathrm{ng} / \mathrm{ml}$ ovine $\mathrm{LH}$ (NIDDK-oLH-26) was added to maximally stimulate testosterone production; the goal being to detect any alteration in the capacity of the fetal Leydig cell to produce testosterone. Incubations were carried out in $5 \% \mathrm{CO}_{2}$ at $34{ }^{\circ} \mathrm{C}$ for $3 \mathrm{~h}$. Medium from each well was transferred to a microcentrifuge tube and stored at $-70^{\circ} \mathrm{C}$ for testosterone assay. Testosterone RIA was performed using a radiolabeled antibody kit (Coat-A-Count, Siemens Healthcare Diagnostic, Tarrytown, NY, USA) according to the manufacturer's instructions. Intra-assay and inter-assay coefficients of variation for the assay were both $<10 \%$. Each of the four testes/litter following the incubations was transferred to a microfuge tube and stored at $-70{ }^{\circ} \mathrm{C}$ until extracts for the proteomic evaluation were prepared.

\section{Quantitative evaluation of the GD 19 testis proteome}

GD19 testes (4/I) were held at $-70{ }^{\circ} \mathrm{C}$ until extracts were prepared for 2D SDS-PAGE as previously described (Kaydos et al. 2004). Upon thawing, the testes were homogenized in a $1 \mathrm{ml}$ glass-glass homogenizer in $1 \mathrm{ml} 10 \mathrm{mM}$ Tris buffer containing $1 \mathrm{mM}$ EDTA, $0.5 \%$ 3-[(3-cholamidopropyl)dimethylammonio]-1-propanesulfonate, $0.25 \% \mathrm{OBG}, \mathrm{pH} 7.2$, to which $0.2 \mathrm{mM}$ phenylmethylsulphonyl fluoride was freshly added. Each homogenate was desalted and concentrated in Ultrafree-4 centrifugation filter units (Millipore, Bedford, MA,

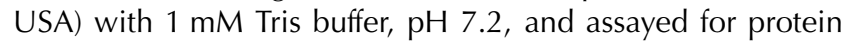
using Micro-BCA protein assay kit (\#23235, Pierce, Rockville, IL, USA) before quantitative 2D SDS-PAGE analysis.

Sample volumes containing $30 \mu \mathrm{g}$ of protein were lyophilized, and protein was solubilized for $30 \mathrm{~min}$ at room temperature in $45 \mu \mathrm{l}$ of sample buffer consisting of $5.7 \mathrm{~g}$ urea, $4 \mathrm{ml}$ of $10 \%$ NP-40, $0.5 \mathrm{ml}$ ampholytes (3-10 only; Serva, Heidelberg, Germany), and $0.1 \mathrm{~g}$ of dithiothreitol per $10 \mathrm{ml}$. Isoelectric focusing $(750 \mathrm{~V}, 3.5 \mathrm{~h})$ was carried out in capillary tube gels consisting of $6.24 \mathrm{~g}$ urea, $1.5 \mathrm{ml}$ acrylamide solution (30\% acrylamide, $1.2 \%$ bisacrylamide), $2.25 \mathrm{ml}$ of $10 \%$ NP-40, and $0.65 \mathrm{ml}$ ampholytes (3-10 only) per $10 \mathrm{ml}$. Molecular weight separation was carried out in mini $14 \%$ acrylamide gels $(200 \mathrm{~V}, 1 \mathrm{~h})$. Gels were fixed in $40 \%$ ethanol $(\mathrm{v} / \mathrm{v})$ and $10 \%$ acetic acid $(\mathrm{v} / \mathrm{v})$ in ultrapure water, fluorescence stained using Krypton Protein Stain (Pierce Biotechnology) and, finally, immersed in destaining solution (5\% acetic acid in ultrapure water) for $5 \mathrm{~min}$. A Fluorescent Image Analyzer (FLA-5100; Fujifilm, GE Health Care, Piscataway, NJ, USA) was used to scan gels and capture high-resolution images with a $532 \mathrm{~nm}$ laser light source. Progenesis Same Spots Software (2.0) was used for background correction, spot matching, and spot area quantification. Protein spots from every gel were aligned to a reference gel (Supplementary Figure 7) which was selected from among the treatment groups as a representative profile. Once accurately aligned, quantitative analysis was performed on spot optical densities.

Spots corresponding to proteins whose expression was significantly altered (upregulated or downregulated) at both 10 and 100 mg exposures were punched from 2D gels using an automated Ettan spot picker (GE Healthcare). Gel punches were destained twice in i) $50 \mu \mathrm{l}$ of $200 \mathrm{mM}$ ammonium bicarbonate, $40 \%(\mathrm{v} / \mathrm{v})$ acetonitrile, and ii) $25 \mathrm{mM}$ ammonium bicarbonate in 50\% (v/v) acetonitrile, and dehydrated with acetonitrile under vacuum. Gel punches were rehydrated in $10 \mu \mathrm{l}$ proteomics grade trypsin (Sigma, Cat \# T 6567, $20 \mu \mathrm{g} / \mathrm{ml}$ ) dissolved in trypsin reaction buffer $(40 \mathrm{mM}$ ammonium bicarbonate, $2 \%(\mathrm{v} / \mathrm{v})$ acetonitrile). After $2 \mathrm{~h}$, a $20 \mu \mathrm{l}$ aliquot of the trypsin reaction buffer was added, and the digests were incubated overnight in an Eppendorf thermomixer at $37^{\circ} \mathrm{C}$, $80 \mathrm{~g}$. Finally, $5 \mu \mathrm{l}$ aliquot of $3 \%$ aqueous trifluoroacetic acid was added and the peptide mixture was desalted using C18 Ziptips (Millipore, Billerica, MA, USA). The samples were eluted in $0.7-1.0 \mu \mathrm{l}$ of $\alpha$-cyano-4-hydroxycinnamic acid MALDI matrix dissolved in $0.1 \%$ trifluoroacetic acid in a $4: 1$ acetonitrile:water mixture, which was sufficient to create three MALDI spots per sample. The first two spots were used directly for MALDI-MS and data-dependent MS/MS analysis, and the remaining spot was used for mass-selected MALDI-MS/MS.

\section{Protein identification by mass spectrometry}

Proteins were identified using a 4800 MALDI TOF/TOF (Applied Biosystems (AB), Foster City, CA, USA) mass spectrometer. The on-line proteomics software 'Aldente' (http://expasy.org/tools/ aldente) was used to identify proteins from backgroundsubtracted MALDI-MS data. This step was followed by MALDI-MS/MS sequencing, and the final protein identification was done using Protein Pilot 3.0 software $(A B)$, searching against the rat species sub-database of the SwissProt protein database (http://expasy.org/sprot/). Mass-selected MALDI-MS/MS spectra acquisition was performed to increase protein sequence coverage. The MS peaks selected by Aldente were used to acquire more MS/MS data from the remaining MALDI spots. The reported proteins were identified based on at least two highquality peptide sequence identifications characterized by the Protein Pilot probability peptide MS/MS score of 95 or better. Finally, proteins that were predictive of treatment and correlated with testosterone production or Leydig cell clustering were subjected to pathway analysis (Ingenuity Pathway Analysis).

\section{Western blotting}

Two proteins that were identified as predictive and both upregulated by DEHP exposure were also probed by western blotting. HSPA8 was predictive of large Leydig cell clusters and 
decreased testosterone production. YWHAE was predictive of DEHP treatment. P450scc (Cyp11a1) was probed to confirm lack of altered expression at both 10 and $100 \mathrm{mg} / \mathrm{kg}$. The three polyclonal primary antibodies for these proteins were as follows: goat anti-HSPA8 (sc-1059, Santa Cruz Biotechnology, Santa Cruz, CA, USA), rabbit anti-YWHAE (sc-1020, Santa Cruz Biotechnology), and goat-anti Cyp11a1 (P450scc; sc-1043, Santa Cruz Biotechnology). The secondary antibodies were conjugated with Alexa Fluor 680. These were donkey anti-goat Ig (A21084, Invitrogen) and goat anti-rabbit Ig (21076, Invitrogen).

Samples $(10 \mu \mathrm{g})$ representing each treatment group were loaded onto precast Novex 14\% Tris-glycine mini resolving gels (EC6485BOX, Life Technologies). Following electrophoresis proteins were transferred onto nitrocellulose membrane (iBlot transfer stacks; IB3010-02, Invitrogen) using the iBlot system (Invitrogen). After transfer the membrane was removed from the anode stack and incubated for $1 \mathrm{~h}$ at room temperature on an orbital shaker in Odyssey blocking buffer (\#927-40000, Licor, Lincoln, NE, USA): membranes were incubated with primary antibody diluted 1:500 or 1:1000 in blocking buffer overnight in the cold. Membranes were washed four times in Dulbeccos PBS (DPBS) with $0.1 \%$ Tween-20 before incubating with secondary antibody diluted 1:25 000 for $1 \mathrm{~h}$ at room temperature. Finally, the membranes were washed four times in DPBS with Tween followed by three washes in DPBS alone. The membranes were scanned using an Odyssey infrared imaging system (Licor).

\section{Testis histology and immunohistochemistry}

Testis histology and immunohistochemistry was carried out as described previously (Tarka-Leeds et al. 2003). The GD19 testes were immersion fixed in 5\% glutaraldehyde (\#01909; Polysciences, Warrington, PA, USA) in $0.05 \mathrm{M}$ collidine buffer with $0.1 \mathrm{M}$ sucrose overnight at $48{ }^{\circ} \mathrm{C}$. The tissue was rinsed twice with $0.2 \mathrm{M}$ collidine buffer for $5 \mathrm{~min}$. Tissue was postfixed in $1 \%$ aqueous osmium tetroxide (\#223A; Polysciences) in $0.05 \mathrm{M}$ collidine buffer on ice for 1 to $2 \mathrm{~h}$ followed by a 5 -min rinse in $0.2 \mathrm{M}$ collidine. Dehydration consisted of two 5-min washes in 70, 80, and 95\% ethanol on ice, and finally three $20 \mathrm{~min}$ washes in $100 \%$ ethanol at room temperature. After two 10-min rinses in propylene oxide, a $1 \mathrm{~h}$ incubation in propylene oxide:Epon (1:1) and an overnight incubation $\left(48^{\circ} \mathrm{C}\right)$ in $100 \%$ Epon, tissues were embedded in $100 \%$ fresh Epon at $60{ }^{\circ} \mathrm{C}$ for $48 \mathrm{~h}$. Semi-thin $(1 \mu \mathrm{m})$ sections were cut with an RMS Ultramicrotome (MT-7; RMC, Inc., Tucson, AZ, USA) and stained with an aqueous solution of toluidine blue (\#02205; Electron Microscopy Sciences, Fort Washington, PA, USA).

Tissue blocks showing conspicuous dysgenetic lesions were processed for further ultrastructural characterization. Thin sections $(60-80 \mathrm{~nm})$ were cut and stained with uranyl acetate and lead citrate and examined using a transmission electron microscope (JEOL-1200EX, JEOL USA, Inc., Peabody, MA, USA).

For the immunohistochemistry, testes were fixed in formaldehyde, transferred to $70 \%$ ethanol, rinsed two times in $95 \%$ ethanol for $15 \mathrm{~min}$, three times in $100 \%$ ethanol for
$20 \mathrm{~min}$, and two times in $100 \%$ xylene for $30 \mathrm{~min}$. Tissue was incubated in a 1:1 xylene:paraffin (Paraplast Plus; Oxford Labwares, St Louis, MO, USA) bath at $60{ }^{\circ} \mathrm{C}$, two times for $45 \mathrm{~min}$, and then three times for $30 \mathrm{~min}$ in a $100 \%$ paraffin bath at $60{ }^{\circ} \mathrm{C}$. Paraffin blocks were allowed to cool overnight and then stored at $4{ }^{\circ} \mathrm{C}$ until sections $(4-6 \mu \mathrm{m})$ were obtained. After sectioning, the slides were held at room temperature overnight and then stored at $4{ }^{\circ} \mathrm{C}$.

To identify Leydig cells, 3 $\beta$-HSD was immunolocalized. Sections were deparaffinized via a graded ascending series of ethanol and xylene and microwaved at low power for $60 \mathrm{~s}$ in $0.01 \mathrm{M}$ sodium citrate buffer containing $0.05 \%$ Tween 20, pH 6 for antigen retrieval. Sections were washed two times in DPBS and then blocked in DPBS containing 1\% protease-free BSA (\#A-3294, Sigma) for $30 \mathrm{~min}$, incubated for $15 \mathrm{~min}$ at room temperature in $3 \% \mathrm{H}_{2} \mathrm{O}_{2}$ in $\mathrm{dH}_{2} \mathrm{O}$, and again washed two times in DPBS. Slides were incubated overnight at $4{ }^{\circ} \mathrm{C}$ in rabbit anti3 $\beta$-HSD antibody ( $\mathrm{H}-143$, Santa Cruz Biotechnology), diluted 1:200 in PBS containing 1.0\% BSA, and then washed two times in PBS. Following a 1-h incubation at room temperature with biotinylated anti-rabbit IgG (BA 1400: R.T.U. biotinylated universal anti-rabbit/mouse; Vector Laboratories, Burlingame, CA, USA) diluted 1:100 in PBS, sections were washed twice in PBS, incubated for $1 \mathrm{~h}$ with avidin-biotin peroxidase complex (PK7100: Vectastain R.T.U. Elite ABC reagent; Vector Laboratories), and washed twice with PBS. Bound antibody was localized with Vector DAB peroxidase substrate kit (\#SK-4100; Vector Laboratories). Sections were washed in $\mathrm{dH}_{2} \mathrm{O}$ and counterstained with hematoxylin. Slides were rinsed in running tap water and dehydrated through a graded descending ethanol series, and coverslips were mounted with Vectamount (H-5000; Vector Laboratories).

The two proteins that were identified as predictive and probed by western blotting were also immunolocalized in the GD19 testis. HSPA8 was identified as predictive of large Leydig cell clusters and decreased testosterone production. YWHAE was identified as predictive of DEHP treatment. The primary antibodies for these proteins were the same as those used for western blotting and were used at 1:200. The secondary for YWHAE was the same as that used to localize 3B-HSD, the secondary for HSPA8 was a biotinylated anti-goat (BA-5000; Vector Laboratories). Each was used at 1:100. Sections were evaluated using a Leica DM6000B microscope and images were captured with a Leica DFC295 color camera.

\section{Estradiol in the GD19 fetus}

Because of the surprising outcome of the pathway analysis indicating a role for estradiol in the observed protein spectrum, we undertook a follow-up study. For this study, 15 timedpregnant Sprague-Dawley rats (Charles Rivers Laboratories, Inc.) were allowed to acclimate for 1 week and randomly assigned based on body weight ranking on GD11 to either control or $100 \mathrm{mg}$ DEHP/kg groups ( $n=7$ each). DEHP was administered from GD13-GD19 as before and after the last dose on GD19, litters were evaluated. Dams were decapitated and pups were delivered via Cesarean section. Pups were then placed in numbered dishes kept on a slide warmer maintained at $37^{\circ} \mathrm{C}$. Fetal trunk blood was collected into heparinized 
capillary tubes. Sex of each fetus was ascertained and male and female fetal blood was pooled by litter into siliconized $1.5 \mathrm{ml}$ centrifugation tubes. Plasma was separated by centrifugation and frozen immediately at $-70{ }^{\circ} \mathrm{C}$. Plasma concentrations of estradiol were measured using the Ultra-Sensitive Estradiol RIA kit following the manufacturer's instructions (DSL4800, Beckman Coulter, Webster, TX, USA). The limit of detection was $1.2 \mathrm{pg} / \mathrm{ml}$.

\section{Statistical analysis}

For testosterone and proteomic evaluations 16 I were evaluated per treatment group $(n=16)$. Both testosterone and protein data were analyzed using two-way ANOVA (PROC GLM; SAS 9.1, 2002-2003) for treatment effects. As absolute values for individual proteins between control testes in the two experiments differed, individual protein data were converted to percent of control for the ANOVA analysis. A correlation analysis was performed to determine whether significant $(P<0.05)$ correlations existed within an animal for treatment, testosterone production, small Leydig cell clusters (2-5 LCs/cluster), large Leydig cell clusters (>5 LCs/cluster), and the individual proteins that were significantly altered at both 10 and $100 \mathrm{mg} / \mathrm{kg}$ DEHP exposure. For this, the backgroundcorrected spot density for each protein was used. To determine whether individual proteins could be used to predict treatment, decreased testosterone production, and/or Leydig cell clustering, a linearized, discriminant analysis program was used (PROC DISCRIM; SAS 9.1, 2002-2003). For discriminant analysis treatment, classifications were 0,10 , and $100 \mathrm{mg} / \mathrm{kg}$. For testosterone production, classifications were based on the mean (expressed as \% of control) per treatment group, i.e. $100 \%$ control $(0 \mathrm{mg} / \mathrm{kg}), 89 \%$ of control $(10 \mathrm{mg} / \mathrm{kg})$, and $43 \%$ of control $(100 \mathrm{mg} / \mathrm{kg})$. For Leydig cell, clustering classifications were based on the means of small and large clusters within each treatment group. For small clusters, means were $9(0 \mathrm{mg} / \mathrm{kg}), 14(10 \mathrm{mg} / \mathrm{kg})$, and $5.75(100 \mathrm{mg} / \mathrm{kg})$. For large cluster, means were $3(0 \mathrm{mg} / \mathrm{kg}), 7.25(10 \mathrm{mg} / \mathrm{kg})$, and 11 $(100 \mathrm{mg} / \mathrm{kg})$. Plasma estradiol concentration data were evaluated for a treatment effect using a two-tailed Student's $t$-test with GraphPad InStat 3 (GraphPad Software, La Jolla, CA, USA). Data were tested for normality using the Kolmogorov-Smirnov test before statistical analysis.

\section{Supplementary data}

This is linked to the online version of the paper at http://dx.doi. org/10.1530/REP-12-0266.

\section{Declaration of interest}

Disclaimer: This manuscript has been reviewed in accordance with the policy of the National Health and Environmental Effects Research Laboratory, U.S. EPA, and approved for publication. Approval does not signify that the contents necessarily reflect the views or policy of the Agency, nor does mention of trade names or commercial products constitute endorsement or recommendation for use.

\section{Funding}

This research did not receive any specific grant from any funding agency in the public, commercial or not-for-profit sector.

\section{Acknowledgements}

The authors thank Christy Lambright and Johnathan Furr for assistance with dissection and preparation of testes for testosterone incubations and histology, and Susan Jeffay for management of the testosterone incubations. They also thank Jennifer Palmer and Carol Moeller for assistance with transmission electron microscopy.

\section{References}

Agency for Toxic Substances and Disease Registry 2006 Toxicological profile for di(2-ethylhexyl) phthalate) (DEHP) Agency for Toxic Substances and Disease Registry, Atlanta GA, www.atsdr.cdc.gov/ toxprofiles/tp9.html.

Akingbemi BT, Ge R, Klinefelter GR, Zirkin BR \& Hardy MP 2004 Phthalate-induced Leydig cell hyperplasia is associated with multiple endocrine disturbances. PNAS 101 775-780. (doi:10.1073/pnas. 0305977101)

Akre O \& Richiardi L 2009 Does a testicular dysgenesis syndrome exist? Human Reproduction 24 2035-2060. (doi:10.1093/humrep/dep174)

Ballif BA, Cao Z, Schwartz D, Carraway KL \& Gygi SP 2006 Identification of 14-3-3 epsilon substrates from embryonic murine brain. Journal of Proteome Research 5 2372-2379. (doi:10.1021/pr060206k)

Blair RM, Fang H, Branham WS, Hass BS, Dial SL, Moland CL, Tong W, Shi L, Perkins R \& Sheeban DM 2000 The estrogen receptor relative binding affinities of 188 natural and xenochemicals: structural diversity of ligands. Toxicological Sciences 54 138-153. (doi:10.1093/toxsci/54. 1.138)

Borch J, Metzdorff SB, Vinggaard AM, Brokken L \& Dalgaard M 2006 Mechanisms underlying the anti-androgenic effects of diethylhexyl phthalate in fetal rat testis. Toxicology 223 144-155. (doi:10.1016/ j.tox.2006.03.015)

Boukari K, Ciampi ML, Guiochon-Mantel A, Young J, Lombes M \& Meduri G 2007 Human fetal testis: source of estrogen and target of estrogen. Human Reproduction 22 1885-1892. (doi:10.1093/humrep/ dem091)

Carlsen I, Giwercman A, Keiding N \& Skakkebaek NE 1992 Evidence for decreasing quality of semen during past 50 years. BMJ 305 609-613. (doi:10.1136/bmj.305.6854.609)

Cederroth CR, Schaad O, Descombes P, Chambon P, Vassalli J-D \& Nef S 2007 Estrogen receptor a is a major contributor to estrogen-mediated fetal testis dysgenesis and cryptorchidism. Endocrinology $\mathbf{1 4 8}$ 5507-5519. (doi:10.1210/en.2007-0689)

Delbes G, Levacher C \& Habert R 2006 Estrogen effects on fetal and neonatal testicular development. Reproduction 132 527-538. (doi:10.1530/rep.1.01231)

Duplessis TT, Williams CC, Hill SM \& Rowan BG 2011 Phosphorylation of estrogen receptor $\alpha$ at serine 118 directs recruitment of promoter complexes and gene-specific transcription. Endocrinology 152 2517-2526. (doi:10.1210/en.2010-1281)

Fisch H 2008 Declining worldwide sperm counts: disproving a myth. Urologic Clinics of North America 35 137-146. (doi:10.1016/j.ucl.2008. 01.001)

Gaido KW, Henslely JB, Liu D, Wallace DG, Borghoff S, Johnson KJ, Hall SJ \& Boekelheide K 2007 Fetal mouse phthalate exposure shows that gonocyte multinucleation is not associated with decreased testicular testosterone. Toxicological Sciences 97 491-503. (doi:10.1093/toxsci/ kfm049)

Gray LE Jr, Ostby J, Furr J, Price M, Veeramachaneni DN \& Parks L 2000 Perinatal exposure to the phthalates DEHP, BBP, and DINP, but not DEP, DMP, or DOTP, alters sexual differentiation of the male rat. Toxicological Sciences 58 350-365. (doi:10.1093/toxsci/58.2.350) 
Guo QM, Malek RL, Sim S, Chiao C, He M, Ruffy M, Sanka K, Lee NH, Dang CV \& Liu ET 2000 Identification of c-myc responsive genes using rat cDNA microarray. Cancer Research 60 5922-5928.

Hallmark N, Walker M, McKinnell C, Mahood K, Scott H, Bayne R, Coutts S, Anderson RA, Greig I, Morris K et al. 2007 Effects of monobutyl and di(n-butyl) phthalate in vitro on steroidogenesis and Leydig cell aggregation in fetal testis explants from the rat: comparison with effects in vivo in the fetal rat and neonatal marmoset and in vitro in the human. Environmental Health Perspectives 115 390-396. (doi:10.1289/ehp. 9490)

Hannas BR, Lambright CS, Furr J, Howdeshell KL, Wilson VS \& Gray LE 2011 Dose-response assessment of fetal testosterone production and gene expression levels in rat testes following in utero exposure to diethylhexyl phthalate, diisobutyl phthalate, diisoheptyl phthalate, and diisononyl phthalate. Toxicological Sciences 123 206-216. (doi:10.1093/toxsci/kfr146)

Howdeshell KL, Furr J \& Lambright CR 2007 Gestational and lactational exposure to ethinyl estradiol, but not bisphenol a, decreases androgen dependent reproductive organ weights and epididymal sperm abundance in the male Long Evans hooded rat. Toxicological Sciences 102 371-382. (doi:10.1093/toxsci/kfm306)

Huhtaniemi I \& Pelliniemi LJ 1992 Fetal Leydig cells: cellular origin, morphology, life span, and special functional features. Proceedings of the Society of Experimental Biology and Medicine 201 125-140.

Hutson JM, Watts LM, Montalto G \& Greco S 1990 Both gonadotropin and testosterone fail to reverse estrogen-induced cryptorchidism in fetal mice: further evidence for nonandrogenic control of testicular descent in the fetus. Pediatric Surgery International 5 13-18. (doi:10.1007/ BF00179631)

Kapyaho D, Poso J \& Janne J 1980 Role of propylamine transferases in hormone-induced stimulation of polyamine biosynthesis. Biochemical Journal 192 59-63.

Kaydos EH, Suarez JD, Roberts NL, Bobseine K, Zucker R, Laskey J \& Klinefelter GR 2004 Haloacid induced alterations in fertility and the sperm biomarker SP22 in the rat are additive: validation of an ELISA. Toxicological Sciences 81 430-442. (doi:10.1093/toxsci/kfh218)

Lambrot R, Muczynski V, Lecureuil C, Angenard G, Coffigny H, Pairault C, Moison D, Frydman R, Habert R \& Rouiller-Fabre V 2009 Phthalates impair germ cell development in the human fetal testis in vitro without change in testosterone production. Environmental Health Perspectives 117 32-37. (doi:10.1289/ehp.1174c32)

Lefevre PL, Palin MF \& Murphy BD 2011 Polyamines on the reproductive landscape. Endocrine Reviews 32 694-712. (doi:10.1210/ er.2011-0012)

Lehmann KP, Phillips S, Sar M, Foster PMD \& Gaido DW 2004 Dosedependent alterations in gene expression and testosterone synthesis in the fetal testes of male rats exposed to di(n-butyl) phthalate. Toxicological Sciences 81 60-68. (doi:10.1093/toxsci/kfh169)

Lehraiki A, Racine C, Krust A, Habert R \& Levacher C 2009 Phthalates impair germ cell number in the mouse fetal testis by an androgen- and estrogen-independent manner. Toxicological Sciences 111 372-382. (doi:10.1093/toxsci/kfp153)

Lin H, Ge RS, Chen GR, Hu GX, Dong L, Lian QQ, Hardy DO, Sottas CM, Li XK \& Hardy MP 2008 Involvement of testicular growth factors in fetal Leydig cell aggregation after exposure to phthalate in utero. PNAS 105 7218-7222. (doi:10.1073/pnas.0709260105)

Mahood IK, McKinnell C, Walker M, Hallmark N, Scott H, Fisher JS, Rivas A, Hartung S, Ivell R, Mason I et al. 2006 Cellular origins of testicular dysgenesis in rats exposed in utero to di(n-butyl) phthalate. International Journal of Andrology 29 148-154. (doi:10.1111/j.13652605.2005.00574.x)

Manthey D, Heck S, Engert S \& Behl C 2001 Estrogen induces a rapid secretion of amyloid $\beta$ precursor protein via the mitogen-activated protein kinase pathway. European Journal of Biochemistry 268 4285-4291. (doi:10.1046/j.1432-1327.2001.02346.x)

Maselli J, Hales BF, Chan P \& Robaire B 2012 Exposure to bleomycin, etoposide, and cis-platinum alters rat sperm chromatin integrity and sperm head protein profile. Biology of Reproduction 86 1-10. (doi:10.1095/biolreprod.111.098616)

McConnell MJ, Chevallier N, Berkofsky-Fessler W, Giltnane JM, Malani RB, Staudt LM \& Licht JD 2003 Growth suppression by acute promyelocytic leukemia associated protein PLZF is mediated by repression of c-myc expression. Molecular and Cellular Biology 23 9375-9388. (doi:10.1128/MCB.23.24.9375-9388.2003)

Meeker JD, Sathyanarayana S \& Swan SH 2009 Phthalates and other additives in plastics: human exposure and associated health outcomes. Philosophical Transactions of the Royal Society of London. Series B: Biological Sciences 364 2097-2113. (doi:10.1098/rstb.2008.0268)

Mercier I, Casimiro MC, Zhou J, Wang C, Plymire C, Bryant KG, Deumer KM, Sotgia F, Bonuccelli G, Witkiewicz AK et al. 2009 Genetic ablation of caveolin-1 drives estrogen hypersensitivity and the development of DCIS-like mammary lesions. American Journal of Pathology $17 \mathbf{4}$ 1172-1190. (doi:10.2353/ajpath.2009.080882)

Mitchell RT, Childs AJ, Anderson RA, van den Driesche S, Saunders PTK, McKinnell C, Wallace WHB, Kelnar CJH \& Sharpe RM 2012 Do phthalates affect steroidogenesis by the human fetal testis? Exposure of human fetal testis xenografts to di-n-butyl phthalate Journal of Clinical Endocrinology and Metabolism 97 E341-E348. (doi:10.1210/jc.20112411)

Mizrak SC, Bogerd J, Lopez-Casas PP, Parraga M, Del Mazo J \& de Rooij DG 2006 Expression of stress inducible protein 1 (Stip1) in the mouse testis. Molecular Reproduction and Development 73 1361-1366. (doi:10.1002/mrd.20548)

Mylchreest E, Cattley RC \& Foster PMD 1998 Male reproductive tract malformations in rats following gestational and lactational exposure to di(n-butyl) phthalate: an antiandrogenic mechanism? Toxicological Sciences 43 47-60.

Mylchreest E, Wallace DG, Cattley RC \& Foster PMD 2000 Dosedependent alterations in androgen-regulated male reproductive development in rats exposed to di(n-butyl) phthalate during late gestation. Toxicological Sciences 55 143-151. (doi:10.1093/toxsci/55.1.143)

O'Donnell L, Robertson KM, Jones ME \& Simpson ER 2001 Estrogen and spermatogenesis. Endocrine Reviews 22 289-318. (doi:10.1210/er. 22.3.289)

Odunuga OO, Hornby JA, Bies C, Zimmerman R, Pugh DJ \& Blatch GL 2003 Tetratricopeptide repeat motif-mediated Hsc70-mSt1 interaction. Molecular characterization of the critical contacts for successful binding and specificity. Journal of Biological Chemistry 278 6896-6904. (doi:10.1074/jbc.M206867200)

Pant N, Shukla M, Patel DK, Shukla Y, Mathur N, Gupta YK \& Saxena DK 2008 Correlation of phthalate exposures with semen quality. Toxicology and Applied Pharmacology 231 112-116. (doi:10.1016/j.taap.2008. 04.001)

Papacontstantinou AD, Fisher BR, Umbreit TH \& Brown KM 2002 Increases in mouse uterine heat shock protein levels are a sensitive and specific response to uterotrophic agents. Environmental Health Perspectives 110 1207-1212. (doi:10.1289/ehp.021101207)

Parks LG, Ostby JS, Lambright CR, Abbott BD, Klinefelter GR, Barlow NJ \& Gray LE 2000 The plasticizer diethylhexyl phthalate induces malformations by decreasing fetal testosterone synthesis during sexual differentiation in the male rat. Toxicological Sciences 58 339-349. (doi:10.1093/toxsci/58.2.339)

Plummer S, Sharpe RM, Hallmark N, Mahood IK \& Elcombe C 2007 Time-dependent and compartment specific effects of in utero exposure to di(n-butyl) phthalate on gene/protein expression in the fetal rat testis as revealed by transcription profiling and laser capture microdissection. Toxicological Sciences 97 520-532. (doi:10.1093/toxsci/ kfm062)

Rozhkova EA, Zatsepina OG, Yurinskaya MM, Vinokurov MG \& Evgeniev MB 2011 Effect of extracellular recombinant human heath shock protein 70 (HSP70) on protein pattern observed after endotoxininduced macrophage activation. Molecular Biology 45 347-351. (doi:10.1134/S0026893311020166)

Sharpe RM \& Skakkebaek NK 2008 Testicular dysgenesis syndrome: mechanistic insights and potential new downstream effects. Fertility and Sterility 89 334-338. (doi:10.1016/j.fertnstert.2007.12.026)

Shultz VD, Phillips S, Sar M, Foster PMD \& Gaido KW 2001 Altered gene profiles in fetal rat testes after in utero exposure to di(n-butyl) phthalate. Toxicological Sciences 64 233-242. (doi:10.1093/toxsci/64.2.233)

Swan S 2008 Environmental phthalate exposure in relation to reproductive outcomes and other health endpoints in humans. Environmental Research 108 177-184. (doi:10.1016/j.envres.2008.08.007) 
Tarka-Leeds DK, Suarez JD, Roberts NL, Rogers JM, Hardy MP \& Klinefelter GR 2003 Gestational exposure to ethane dimethanesulfonate permanently alters reproductive competence in the CD-1 mouse. Biology of Reproduction 69 959-967. (doi:10.1095/biolreprod.103. 017343)

Thompson CJ, Tam NN, Joyce JM, Leav I \& Ho SM 2002 Gene expression profiling of testosterone and estradiol $17 \beta$-induced prostatic dysplasia in Noble rats and response to the antiestrogen ICI 182,780. Endocrinology 143 2093-2105. (doi:10.1210/en.143.6.2093)

Toyo-oka K, Shionoya A, Gambello MJ, Cardoso C, Leventer R, Ward HL, Ayala R, Tsai LH, Dobyns W, Ledbetter D et al. 2003 14-3-3 epsilon is important for neuronal migration by binding to NUDEL: a molecular explanation for Miller-Dieker syndrome. Nature Genetics 34 274-285. (doi:10.1038/ng1169)

Veeramachaneni DN 2006 Germ cell atypia in undescended testes hinges on the aetiology of cryptorchidism but not the abdominal location per se. International Journal of Andrology 29 235-240. (doi:10.1111/j.1365 2605.2005.00565.x)

Veeramachaneni DN, Sherman GB, Floyd JG, Ott RS \& Hixon JE 1988 Zeranol and estradiol induce similar lesions in the testes and epididymides of the prepubertal beef bull. Fundamental and Applied Toxicology 10 73-81. (doi:10.1016/0272-0590(88)90252-7)

Voloboueva LA, Duan M, Ouyang Y, Emery JF, Stoy C \& Giffard RG 2008 Overexpression of mitochondrial Hsp70/Hsp75 protects astrocytes against ischemic injury in vitro. Journal of Cerebral Blood Flow and Metabolism 28 1009-1016. (doi:10.1038/sj.jcbfm.9600600)

Wang C, Mayer JA, Mazumdar A, Fertuck K, Kim H, Brown M \& Brown PH 2011 Estrogen induces c-myc gene expression via an upstream enhancer activated by the estrogen receptor and the AP-1 transcription factor. Molecular Endocrinology 25 1527-1538. (doi:10.1210/me.20111037)

Watanabe H, Suzuki A, Kobayashi M, Lubahn DB, Handa H \& Iguchi T 2003 Similarities and differences in uterine gene expression patterns caused by treatment with physiological and non-physiological estrogens. Journal of Molecular Endocrinology 31 487-497. (doi:10.1677/jme.0. 0310487)

Whitesell L \& Lindquist SL $2005 \mathrm{Hsp} 90$ and the chaperoning of cancer. Nature Reviews. Cancer 5 761-772. (doi:10.1038/nrc1716)

Wilhelm D, Huang E, Svingen T, Stanfield S, Dinnis D \& Koopman P 2006 Comparative proteomic analysis to study molecular events during gonad development in mice. Genesis 44 168-176. (doi:10.1002/dvg.20200)

Zhang F-P, Hamalainen T, Kaipia A, Pakarinen P \& Huhtaniemi I 1994 Ontogeny of luteinizing hormone receptor gene expression in the rat testis. Endocrinology 134 2206-2213. (doi:10.1210/en.134.5.2206)

Zhang W, Shen H, Ma L, Shen B, Xu Z \& Wang X 2007 Differential expression of peroxiredoxin 6 in fetal rat testis following in utero exposure to di(n-butyl) phthalate. Toxicology 240 86-95. (doi:10.1016/j. tox.2007.07.021)

Received 12 July 2012

First decision 10 August 2012

Revised manuscript received 20 September 2012

Accepted 5 October 2012 